\title{
Determination and Modeling of Thermophysical and Transport Properties of Tropical Pulps
}

\author{
Magdiely Stefanes de Santana Varela, Gabriela Cecília Remigio Pitombeira, \\ Ana Cláudia Nascimento Silva, Camila Gambini Pereira
}

Laboratory of Separation Processes in Foods, Department of Chemical Engineering, Federal University of Rio Grande do Norte, Natal, Brazil

\author{
Email address: \\ camila@eq.ufrn.br (C. G. Pereira)
}

\section{To cite this article:}

Magdiely Stefanes de Santana Varela, Gabriela Cecília Remigio Pitombeira, Ana Cláudia Nascimento Silva, Camila Gambini Pereira. Determination and Modeling of Thermophysical and Transport Properties of Tropical Pulps. European Journal of Biophysics. Vol. 5, No. 5, 2017, pp. 79-88. doi: 10.11648/j.ejb.20170505.11

Received: July 26, 2017; Accepted: August 28, 2017; Published: December 19, 2017

\begin{abstract}
The objective of this work was to determine the thermophysical and transport properties of Hancornia speciosa G. ("mangaba"), Annona muricata L. ("graviola"), Eugenia uniflora Berg ("pitanga") pulps. The following properties were evaluated: thermal diffusivity, thermal conductivity, heat capacity, density and coefficient of thermal expansion. Rheological properties were determined and adjusted to three models. The effect of temperature on the rheological behavior was also evaluated. The pulps were further characterized in relation to humidity, ${ }^{\circ}$ Brix, water activity, surface tension, $\mathrm{pH}$ and total acidity. The results indicated agreement with literature in relation to thermophysical and transport properties, and the pulps presented a pseudoplastic behavior. Temperature influenced the pulps properties in different aspects: higher effect on the coefficient of thermal expansion of mangaba pulp, higher effect on the rheological behavior of pitanga pulp. The results presented an important advance for the knowledge of food fluids, being necessary for the processing of these materials.
\end{abstract}

Keywords: Tropical Exotic Pulps, Modeling, Thermophysical and Transport Properties, Rheological Behavior

\section{Introduction}

The knowledge of thermophysical and transport properties of fluids plays an important role in the processing and economic viability of materials from different industrial sectors. The processes of interest may range from preservation processes using temperature, such as concentration, evaporation, pasteurization, to processes which make use of temperature to increase solubility, as in the mixing, extraction, or diffusion of bioactive compounds. The lack of data or the use of uncertain data can decrease the efficiency or even indicates a specific process as infeasible. Parallel, in many cases, one or more thermophysical and transport properties may change between the inlet and the outlet of the equipment, making it difficult to control and optimize the process. It is for these reasons that even with process simulators with large parameter data banks, the studies to evaluate and to determine thermophysical and transport properties are still being conducted [1-3].
Literature has shown several works presenting properties of foods. A recent work compiled thermophysical properties of around 650 foods, including meat, fruits, cereals and dairy products [4]. Besides the experimental data, predictive models of density, thermal conductivity, heat capacity and thermal diffusivity of a wide range of foods were also listed. However, when dealing with foods, their complex compositions present a great influence on these properties. Thereby, even with many works, information of these properties in tropical and exotic fruits is still scare.

Concerning to the transport properties, the rheological studies has been used as the principal way to characterize and to evaluate the fluid dynamic behavior of the most of fluids. The rheology is important for numerous areas, and further, for foods, understanding the rheological behavior is essential. In the food industry, due to the sensibility and the complexity of these materials, the knowledge of the rheology of the fluid is necessary in several stages of processing, such as: i) control, optimization, simulation and project of new processes; ii) evaluation of different traditional process and 
equipment (pipelines, pumps, extruders, mixers, heat exchangers, others); iii) determining of ingredient functionality in product development; iv) development of new products with special characteristics; v) control of the quality of the food in the intermediary and final products; vi) evaluation of food texture and it relation with the shelf life of the product $[3,5]$. For these reasons, the knowledge of rheological properties is decisive to the food processing.

The behavior of fluid foods has been classified according to their proximity or not to the Newtonian fluids. Among the studies involving pulps, some of them are listed in Table 1. The non-Netwtonian behavior observed in fruit pulps has been attributed to the complex interactions among soluble sugars, pectic substances and suspended solids [6].

Table 1. Short review of rheological model parameters of fruit pulps.

\begin{tabular}{|c|c|c|c|c|}
\hline Food & Model Fitted & Model parameters & Temperature $\left({ }^{\circ} \mathbf{C}\right) /{ }^{\circ}$ Brix & Ref \\
\hline Araça (Psidium cattleianum sabine) pulp & Power-Law & $\begin{array}{l}\kappa\left(\mathrm{Pa} . \mathrm{s}^{\mathrm{n}}\right)=13.52-32.66 \\
\mathrm{n}=0.17-0.25\end{array}$ & $10-60^{\circ \circ} \mathrm{C} /$ n.i. & [7] \\
\hline \multirow{7}{*}{ Acerola (Malpighia spp.) pulp } & Power-Law & $\begin{array}{l}\kappa\left(P a . s^{\mathrm{n}}\right)=10.381-38.629 \\
\mathrm{n}=0.161-0.286\end{array}$ & \multirow{7}{*}{$5-85^{\circ} \mathrm{C} / 13^{\circ} \mathrm{Brix}$} & \multirow{7}{*}[8]{} \\
\hline & \multirow{2}{*}{ Cassol } & $\tau_{0, \mathrm{c}}(\mathrm{Pa})=4.342-7.394$ & & \\
\hline & & $\kappa_{\mathrm{c}}\left(\mathrm{Pa}_{\mathrm{s}} \mathrm{s}^{\mathrm{n}}\right)=0.142-0.170$ & & \\
\hline & \multirow{2}{*}{ Mizhari-Berk } & $\tau_{0, \mathrm{mb}}(\mathrm{Pa})=4.270-6.542$ & & \\
\hline & & $\begin{array}{l}\kappa_{, \mathrm{mb}}\left(\mathrm{Pa} . \mathrm{s}^{\mathrm{n}}\right)=0.196-0.561 \\
\mathrm{n}=0.312-480\end{array}$ & & \\
\hline & \multirow[b]{2}{*}{ Herschel-Bulkley } & $\tau_{0}(\mathrm{~Pa})=19.836-45.673$ & & \\
\hline & & $\begin{array}{l}\kappa\left(\mathrm{Pa} . \mathrm{s}^{\mathrm{n}}\right)=0.937-5.504 \\
\mathrm{n}=0.393-0.627\end{array}$ & & \\
\hline \multirow[b]{2}{*}{ Acerola (Malpighia spp.) pulp } & \multirow[b]{2}{*}{ Herschel- Bulkley } & $\tau_{0}(\mathrm{~Pa})=0.12-0.93$ & \multirow[b]{2}{*}{$20-60^{\circ} \mathrm{C} / 5.5-13.5^{\circ} \mathrm{Brix}$} & \multirow[b]{2}{*}{ [9] } \\
\hline & & $\begin{array}{l}\kappa\left(P a \cdot s^{\mathrm{n}}\right)=0.32-13.93 \\
\mathrm{n}=0.32-0.56\end{array}$ & & \\
\hline \multirow{5}{*}{ Butia (Butia eriospatha) pulp } & Power-Law & $\begin{array}{l}\kappa\left(\text { Pa. } \mathrm{s}^{\mathrm{n}}\right)=13.2-20.9 \\
\mathrm{n}=0.159-0.183\end{array}$ & \multirow{5}{*}{ 10-60 ${ }^{\circ} \mathrm{C} / \mathrm{n} . \mathrm{i}}$. & \multirow{5}{*}{ [10] } \\
\hline & \multirow{2}{*}{ Cassol } & $\tau_{0, \mathrm{c}}(\mathrm{Pa})=4.36-5.62$ & & \\
\hline & & $\kappa_{, c}\left(\mathrm{~Pa} . \mathrm{s}^{\mathrm{n}}\right)=0.083-0.127$ & & \\
\hline & \multirow[b]{2}{*}{ Herschel-Bulkley } & $\tau_{0}(\mathrm{~Pa})=19.4-36.5$ & & \\
\hline & & $\begin{array}{c}\kappa\left(P a . s^{\mathrm{n}}\right)=0.281-0.553 \\
\mathrm{n}=0.566-0.789\end{array}$ & & \\
\hline \multirow{3}{*}{ Cupuaçu (T. grandiflorum Schum) pulp } & Power-Law & $\begin{array}{l}\kappa\left(P a . s^{\mathrm{n}}\right)=2.73-5.37 \\
\mathrm{n}=0.23-0.42\end{array}$ & \multirow{3}{*}{$10-60^{\circ} \mathrm{C} / \mathrm{n} . \mathrm{i}$} & \multirow{3}{*}{ [11] } \\
\hline & \multirow[b]{2}{*}{ Herschel-Bulkley } & $\tau_{0}(\mathrm{~Pa})=(-5.10)-10.31$ & & \\
\hline & & $\begin{array}{l}\kappa\left(P a \cdot \mathrm{s}^{\mathrm{n}}\right)=0.14-9.32 \\
\mathrm{n}=0.17-0.82\end{array}$ & & \\
\hline \multirow[b]{2}{*}{ Guava (Psidium guajava) pulp } & \multirow[b]{2}{*}{ Mizhari-Berk } & $\tau_{0, \mathrm{mb}}(\mathrm{Pa})=(-0.4336)-1.8219$ & \multirow[b]{2}{*}{$10-60^{\circ} \mathrm{C} / \mathrm{n} . \mathrm{i}}$. & \multirow[b]{2}{*}[12]{} \\
\hline & & $\begin{array}{l}\kappa, \mathrm{mb}\left(\text { Pa. }_{\mathrm{s}}^{\mathrm{n}}\right)=0.6918-2.6499 \\
\mathrm{n}=0.1062-0.2594\end{array}$ & & \\
\hline \multirow{3}{*}{ Jabuticaba (Myrciaria spp.) pulp } & Power-Law & $\begin{array}{l}\kappa\left(P a \cdot s^{\mathrm{n}}\right)=0.66-1.36 \\
\mathrm{n}=0.43-0.47\end{array}$ & \multirow{3}{*}{ 5-85 ${ }^{\circ} \mathrm{C} /$ n.i. } & \multirow{3}{*}[13]{} \\
\hline & \multirow[b]{2}{*}{ Herschel-Bulkley } & $\tau_{0}(\mathrm{~Pa})=1.05-1.62$ & & \\
\hline & & $\begin{aligned} \kappa & \left(\mathrm{Pa}_{\mathrm{s}}^{\mathrm{n}}\right)=0.20-0.71 \\
\mathrm{n} & =0.58-0.67\end{aligned}$ & & \\
\hline \multirow{5}{*}{ Mango (Mangífera indica L. var. Keitt) pulp } & Power-Law & $\begin{array}{l}\kappa\left(\mathrm{Pa}_{\mathrm{s}}^{\mathrm{n}}\right)=0.65-3.63 \\
\mathrm{n}=0.44-0.61\end{array}$ & & \\
\hline & \multirow{2}{*}{ Cassol } & $\tau_{0, \mathrm{c}}=1.29-2.92$ & $30^{\circ} \mathrm{C} / \mathrm{ni}$ & {$[1]$} \\
\hline & & $\kappa_{\mathrm{c}}\left(\mathrm{Pa} \cdot \mathrm{s}^{\mathrm{n}}\right)=0.18-0.20$ & $30 \mathrm{C} / \mathrm{n} .1$. & [14] \\
\hline & Mizhari-Berk & $\tau_{0}(\mathrm{~Pa})=0.28-0.48$ & & \\
\hline & & $\mathrm{n}=0.16-0.66$ & & \\
\hline & Power-Law model & $\begin{array}{l}\kappa\left(P a . s^{n}\right)=0.65-5.63 \\
\mathrm{n}=0.15-0.24\end{array}$ & & \\
\hline Pineapple (Ananas comusus L.merr var Pérola) & Cassol Model & $\begin{array}{l}\kappa\left(P a . s^{n}\right)=1.11-2.78 \\
\mathrm{n}=0.03-0.04\end{array}$ & $30^{\circ} \mathrm{C} /$ n.i. & {$[14]$} \\
\hline & & $\tau_{0, \mathrm{mb}}(\mathrm{Pa})=1.11-2.05$ & & \\
\hline & Mizhari-Berk & $\begin{array}{l}\kappa_{\mathrm{m}}\left(\mathrm{Pa}_{\mathrm{s}}^{\mathrm{n}}\right)=0.03-0.49 \\
\mathrm{n}=0.2-0.5\end{array}$ & & \\
\hline & Power-Law & $\begin{array}{l}\kappa\left(\text { Pa. } \mathrm{s}^{\mathrm{n}}\right)=0.197-0.463 \\
\mathrm{n}=0.346-0.446\end{array}$ & & \\
\hline Pitanga (Eugenia uniflora L.) pulp & & $\tau_{0}(\mathrm{~Pa})=0.291-0.621$ & $83-97^{\circ} \mathrm{C} / \mathrm{n} . \mathrm{i}$. & [15] \\
\hline & Herschel-Bulkley & $\begin{array}{l}\kappa\left(P a . s^{\mathrm{n}}\right)=0.095-0.189 \\
\mathrm{n}=0.448-0.558\end{array}$ & & \\
\hline
\end{tabular}




\begin{tabular}{|c|c|c|c|c|}
\hline Food & Model Fitted & Model parameters & Temperature $\left({ }^{\circ} \mathrm{C}\right) /{ }^{\circ}$ Brix & Ref \\
\hline \multirow{2}{*}{ Soursop (Annona muricata L.) juice } & Power-Law & $\begin{array}{l}\kappa\left(P a \cdot s^{\mathrm{n}}\right)=0.81-129 \mathrm{~Pa} \mathrm{~s}^{\mathrm{n}}, \\
\mathrm{n}=0.262-0.444\end{array}$ & \multirow{2}{*}{$\begin{array}{l}0.4-68.8^{\circ} \mathrm{C} / \text { n.i. } \\
10-70^{\circ} \mathrm{C}, 10-50^{\circ} \text { Brix }\end{array}$} & \multirow{2}{*}{$\begin{array}{l}{[16]} \\
{[17]}\end{array}$} \\
\hline & Power-Law & $\begin{array}{l}\kappa\left(P a . s^{\mathrm{n}}\right)=0.001-5.219 \\
\mathrm{n}=0.399-1.032\end{array}$ & & \\
\hline \multirow{5}{*}{ Strawberry (Fragraria ananassa) pulp } & Power-Law & $\begin{array}{l}\kappa\left(P a . s^{\mathrm{n}}\right)=2.53-7.39 \\
\mathrm{n}=0.28-0.40\end{array}$ & \multirow{5}{*}{$10-60^{\circ} \mathrm{C} /$ n.i. } & \multirow{5}{*}{ [18] } \\
\hline & \multirow{2}{*}{ Cassol } & $\tau_{0, \mathrm{c}}(\mathrm{Pa})^{0.5}=2.41-3.58$ & & \\
\hline & & $\kappa_{\mathrm{c}}\left(\mathrm{Pa} . \mathrm{s}^{\mathrm{n}}\right)=0.13-0.17$ & & \\
\hline & \multirow[b]{2}{*}{ Herschel-Bulkley } & $\tau_{0}(\mathrm{~Pa})=0.42-11.82$ & & \\
\hline & & $\begin{array}{l}\kappa\left(\mathrm{Pa} . \mathrm{s}^{\mathrm{n}}\right)=0.66-4.51 \\
\mathrm{n}=0.33-0.60\end{array}$ & & \\
\hline
\end{tabular}

n. $\mathrm{i}=$ not informed

Among different types of food, fruits are considered an important source of nutrients in human diet. The Northeast of Brazil is represented by the large variety of tropical fruits, many of them considered exotic. This scenery expands the economy and creates new paths for the formulation of new products and co-products in the food industry. Amongst the exotic regional species of fruits in Brazil, special attention has been given to Hancornia speciosa G. ("mangaba"), Annona muricata L. ("graviola") and Eugenia uniflora Berg ("pitanga") due to their high nutritional value, aromatic and economic regional importance [19-30]. The characterization, and the comprehension of the thermophysical and transport properties of these foods are necessary to their effective use in the commercial scale. In this context, the aim of this work was to characterize pulps of mangaba, graviola, pitanga in relation to the physicochemical properties, as soon as to evaluate the thermophysical and rheological properties. For the rheological study, three models were used to fit the behavior of these fluids, and the effect of temperature was evaluated by Arrhenius equation.

\section{Materials and Methods}

The raw materials used in this study were mangaba pulps (Nordeste fruit; lot 09.11.07), graviola pulps (Nordeste fruit; lot 06.11.07) and pitanga pulps (Bonsuco/ Bonito Agrícola LTDA, lot 18.06.08). The pulps were acquired frozen in local stores and were stored in a domestic refrigerator (Metalfrio, double action, São Paulo, Brazil) at $-10^{\circ} \mathrm{C}$ until the analysis. For the analysis, the pulps were defrosted at ambient temperature.

\subsection{Characterization of the Pulps}

The pulps were characterized regarding the physicochemical properties: $\mathrm{pH}$, total acidity, heat capacity, surface tension, water activity, humidity and ${ }^{\circ}$ Brix, according to the following methodologies:

a) $p H$ : The analysis was made using approximately 5 grams of sample in $50 \mathrm{~mL}$ of distilled water at room temperature. After 10 minutes shaking the sample, the probe was inserted in the sample for the $\mathrm{pH}$ determination (Digimed DMPH-2) to check the $\mathrm{pH}$.

b) Total Acidity: Analysis of total acidity of the pulps was performed based on standard methodology [31]. The samples were titrated with $\mathrm{NaOH}(0,1 \mathrm{~N})$, using phenolphthalein as an indicator acid. The acidity is calculated by the $\mathrm{NaOH}$ spent as follow:

$$
\operatorname{Acid}(\%)=\frac{N \times V_{(\mathrm{NaOH})} \times 100}{m}
$$

where: $\mathrm{N}$ is the normality of the solution, $\mathrm{V}_{(\mathrm{NaOH})}$ is the volume of $\mathrm{NaOH}(\mathrm{mL})$, and $\mathrm{m}$ is the mass of solution $(\mathrm{g})$.

c) Heat Capacity $\left(C_{p}\right)$ : it was determined using the following equation (2):

$$
\alpha=\frac{k}{C_{p} \times \rho}
$$

where $k$ is thermal conductivity, $\alpha$ is thermal conductivity, and $\rho$ is of the fluid. These last properties were determined as described in the section 2.2.

d) Surface Tension: The surface tension was measured in the tensiometer (Processor Tensiometer KRUSS, K100) with non-diluted sample of the pulp into clean container.

e) Water Activity (Aw): This property measured in the unit Aqualab - Braseq (Model: 3TE Series), using the samples of the equipment in the container.

f) Humidity: This property was determined by measurements in circulating oven with dry air, at $70^{\circ} \mathrm{C}$. The material was kept in the oven until reaching constant weight.

g) ${ }^{o} B R I X$ : The analysis of soluble solids was made in the refractometer RL2 (Nr Model 2720) with the appropriate sample and manual handling of equipment.

\subsection{Thermophysical and Transport Properties}

The determination of thermophysical and transport properties was performed using calibrated (as standard procedure indicated by manufacturer) equipment and the analyses were carried out as described as follows. The thermal conductivity $(\mathrm{k})$ and thermal diffusivity $(\alpha)$ were measure introducing the probe of the instrument meter KD2 (Decagon - Thermal Properties Analyzer) in the non-diluted sample of the sample, at room temperature. The density was determined using a digital densimeter (Anton Paar, model DMA $45000 \mathrm{M}$, Australia). The effect of temperature and ${ }^{\circ}$ 
Brix on density were also carry out varying the temperature from 10 to $70^{\circ} \mathrm{C}$, and ${ }^{\circ}$ Brix, from 10 to 60 , for all samples. With the values of density, it was possible to determine the coefficient of thermal expansion $\left(\alpha_{T},\right)$, by the Equation (3):

$$
\alpha_{T}=\frac{1}{V}\left(\frac{\partial V}{\partial T}\right)_{P}=-\frac{1}{\rho}\left(\frac{\partial \rho}{\partial T}\right)_{P}
$$

\subsection{Rheology}

Rheological measurements were performed in a rheometer (Thermo Haake Rheometer System). The analyses were carried out at $10-60^{\circ} \mathrm{C}$ with variation in the shear rate of 0 to $500 \mathrm{~s}^{-1}$. The experimental data of each pulp was fitted to three rheological models, namely, Newtonian, Power Law (Ostwald-de-Walle) and Herschel-Bulkley, using the equations 4-6, respectively:

$$
\begin{aligned}
& \tau=\mu \gamma \\
& \tau=\kappa \gamma^{n} \\
& \tau=\tau_{0}+\kappa \gamma^{n}
\end{aligned}
$$

where $\tau$ is the shear tension; $\mu$ is the viscosity; $\gamma$ is the share rate; $\kappa$ is the consistency index, $n$ is the behavior index, $\tau_{0}$ is the residual tension.

The effect of temperature on the fluid viscosity was evaluated using the Arrhenius model (Equation 7):

$$
\ln \eta_{a p}=\frac{E_{a}}{R T}+B
$$

where $\eta_{a p}$ is the apparent viscosity, $E_{a}$ is the activation energy, $R$ is the universal constant of gases, $T$ is the absolute temperature, and $B$ is the adjustment parameter.

\section{Results and Discussion}

\subsection{Physicochemical and Thermophysical Properties}

Table 2 shows the physicochemical and thermophysical properties of the pulps evaluated in this work. The higher distinction observed in the samples in terms of

\begin{tabular}{|c|c|c|c|}
\hline \multirow[t]{2}{*}{ Properties } & \multicolumn{3}{|l|}{ Pulp of Fruits } \\
\hline & Mangaba & Graviola & Pitanga \\
\hline Humidity (\%) & $89.22 \pm 0.08$ & $88.52 \pm 0.02$ & $91.83 \pm 0.02$ \\
\hline $\mathrm{pH}$ & 3.45 & $3.973 \pm 0.005$ & $2.970 \pm 0.006$ \\
\hline Acid total $(\%)$ & $9.24 \pm 0.09$ & $7.2 \pm 0.4$ & $11.8 \pm 0.3$ \\
\hline Surface Tension $(\mathrm{mN} / \mathrm{m})$ & $43.91 \pm 0.10$ & $43.0 \pm 0.1$ & $45.04 \pm 0.04$ \\
\hline${ }^{\circ}$ Brix & $7.4 \pm 0.2$ & $9.76 \pm 0.05$ & $8.50 \pm 0.05$ \\
\hline Aw & $0.985 \pm 0.002^{(\mathrm{a})}$ & $0.982 \pm 0.001^{(\mathrm{a})}$ & $0.9896 \pm 0.0005^{(\mathrm{e})}$ \\
\hline Thermal Conductivity $\left(\mathrm{W} / \mathrm{m} .{ }^{\circ} \mathrm{C}\right)$ & $0.52 \pm 0.01^{(\mathrm{d})}$ & $0.41 \pm 0.01^{(\mathrm{c})}$ & $0.51 \pm 0.01^{(\mathrm{f})}$ \\
\hline Thermal Diffusivity $\left(\mathrm{m}^{2} / \mathrm{s}\right)$ & $1.166 \pm 0.005 \times 10^{-7}$ (d) & $1.000 \pm 0.005 \times 10^{-7(\mathrm{c})}$ & $1.200 \pm 0.005 \times 10^{-7(\mathrm{f})}$ \\
\hline Heat Capacity $\left(\mathrm{kJ} / \mathrm{kg} .{ }^{\circ} \mathrm{C}\right)$ & $3.94 \pm 0.09^{(\mathrm{d})}$ & $4.3 \pm 0.10^{\text {(c) }}$ & $4.06 \pm 0.09^{(\mathrm{f})}$ \\
\hline Coefficient of thermal expansion $\left({ }^{\circ} \mathrm{C}^{-1}\right)$ & $2.79 \times 10^{-1(b)}$ & $0.63 \times 10^{-1(b)}$ & $1.23 \times 10^{-1(b)}$ \\
\hline
\end{tabular}
physicochemical properties were in the total acidity. Pitanga pulp presented superior value (11.8\%) when compared with other pulps studied.

Table 2. Physicochemical, Thermophysical and Transport Properties of mangaba, graviola and pitanga pulps.

(a) at $\mathrm{T}=25.0 \pm 0.2 \mathrm{C}$; ${ }^{\text {(b) }}$ at $\mathrm{T}=20.0 \pm 0.1^{\circ} \mathrm{C}$; ${ }^{(\mathrm{c})}$ at $\mathrm{T}=22.4 \pm 0.6^{\circ} \mathrm{C}$; ${ }^{\text {(d) }}$ at $\mathrm{T}=24.0 \pm 0.4^{\circ} \mathrm{C}$; (f) $24.9 \pm 1.4^{\circ} \mathrm{C}$

In relation to the thermophysical properties, an interesting behavior was observed when the properties of these pulps are compared. The thermal conductivity of the pulps decreased in the following sequence: $\mathrm{k}_{\text {mangaba }}>\mathrm{k}_{\text {pitanga }}>\mathrm{k}_{\text {graviola }}$. At the same time, the ${ }^{\circ}$ Brix of these pulps were $\mathrm{B}_{\text {mangaba }}<\mathrm{B}_{\text {pitanga }}<\mathrm{B}_{\text {graviola. }}$. The same effect of ${ }^{\circ}$ Brix on thermal conductivity has been observed for other juices and pulps [32-35]. Cabral et al [32] in the evaluation of thermophysical properties from blackberry juice observed that the thermal conductivity and thermal diffusivity decreased with increasing ${ }^{\circ}$ Brix, however in different proportions, being the thermal conductivity more sensitive of ${ }^{\circ}$ Brix changes then the thermal diffusivity. From experimental data of Cabral et al [32], it is possible to observe that the thermal conductivity decreased around $31 \%$ while the diffusivity only $4 \%$ with increasing of ${ }^{\circ}$ Brix, in the same range of ${ }^{\circ}$ Brix. Here, in our work, the effect of ${ }^{\circ}$ Brix on the thermal conductivity is not being evaluated for a specific pulp. Even comparing different pulps, it's verified that the effect of ${ }^{\circ}$ Brix on the thermal conductivity is coherent with literature: this property decreases with increasing ${ }^{\circ}$ Brix. For thermal diffusivity, according to literature [32], this property decreases with increasing ${ }^{\circ}$ Brix. From Table 2, this behavior occurred from mangaba to graviola. For pitanga, the value obtained the thermal diffusivity was superior to the others. However, according to the results, the pitanga also presented higher amount of water (91.83\% of humidity), and this fact can have contributed to the higher thermal diffusivity of this pulp.

Concerning to heat capacity, literature also has demonstrated direct proportionality to ${ }^{\circ}$ Brix [33]. This behavior was also observed in the present work when the three pulps are compared, i.e, the heat capacity increases in the following sequence: $C_{p \text {,mangaba }}<C_{p \text {,pitanga }}<C_{p \text {, graviola. }}$.

Figure 1 shows the effect of ${ }^{\circ}$ Brix (a) and temperature (b) on the density of the pulps. According to the results presented on Figure 1, in all cases, the density of the pulps increases with ${ }^{\circ}$ Brix from 10 to about 60 and decreases with the temperature from 10 to $70^{\circ} \mathrm{C}$. This behavior is also coherent with literature $[32,33]$. From the results presented 
in Figure 1, the experimental data were fitted to a polynomial equation of second degree for each pulp. These equations are presented in Table 3.

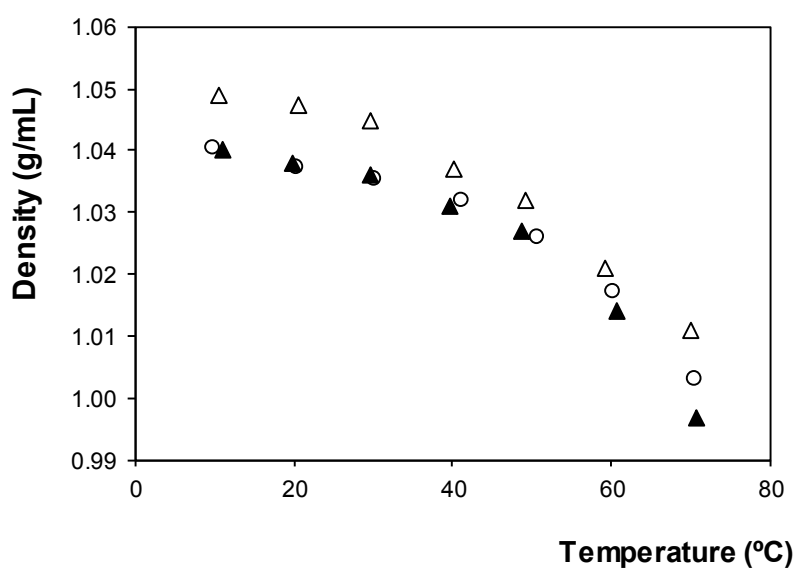

(a)

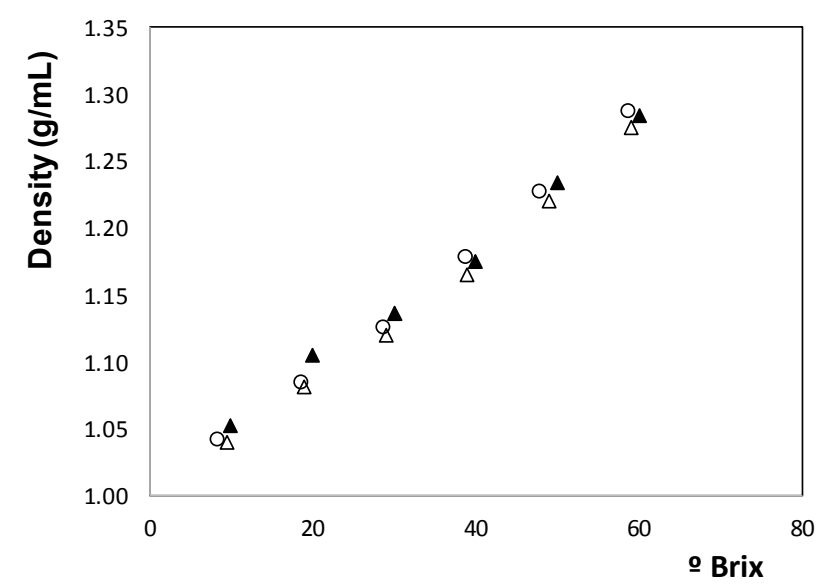

(b)

Figure 1. Effect of (a) temperature and (b) ${ }^{\circ}$ Brix on density of mangaba (4), graviola $(\mathbf{\Lambda})$, pitanga (०).

Table 3. Model fitted to density of mangaba, graviola and pitanga pulps.

\begin{tabular}{lll}
\hline Effect/ Pulp & Mathematical Modeling of Density $(\mathbf{g} / \mathbf{m L})$ & $\mathbf{R}^{2}$ \\
\hline Temperature & & \\
Mangaba pulp & $\rho=-9 \times 10^{-6} T^{2}+7.6 \times 10^{-5} T+1.0496$ & 0.9964 \\
Graviola pulp & $\rho=-1.43 \times 10^{-5} T^{2}+0.498 \times 10^{-3} T+1.0348$ & 0.9900 \\
Pitanga pulp & $\rho=-1.11 \times 10^{-5} T^{2}+0.325 \times 10^{-3} T+1.0369$ & 0.9900 \\
'Brix & & \\
Mangaba pulp & $\rho=0.0047 B+0.9897$ & 0.9948 \\
Graviola pulp & $\rho=0.0045 B+1.0069$ & 0.9923 \\
Pitanga pulp & $\rho=0.0049 B+0.9933$ & 0.9958 \\
\hline
\end{tabular}

Where $\mathrm{T}$ is temperature $\left({ }^{\circ} \mathrm{C}\right)$, and $\mathrm{B}$ is ${ }^{\circ} \mathrm{Brix}$.

With the data of density in function of the temperature it was possible to determine the coefficient of thermal expansion for each pulp (Equation 3, Figure 2). The values of the coefficient of thermal expansion varies from 0.63 to $15.29 \times 10^{-1}{ }^{\circ} \mathrm{C}^{-1}$. According to the results, it's possible to verify that the coefficient of thermal expansion of fruit pulps is inverse to the behavior observed in the density, i.e, increases with the temperature from 10 to $70^{\circ} \mathrm{C}$. This behavior is in agreement with observed for all pulps. On the other hand, when coefficients of thermal expansion of the different pulps are compared, an inversion between the values of the pulps is verified. At low temperatures, the coefficient of thermal expansion of the mangaba pulp is lower than that observed for graviola pulp. However, the opposite was observed at higher temperatures, i.e, the coefficient of thermal expansion of mangaba is higher than that observed for graviola. In fact, it is due to the effect of temperature on the volume of the pulps. It means that temperature has more effect on mangaba pulp than on graviola pulp. The thermal expansion coefficient, also called volumetric expansion ratio or volume expansivity indicates the amount of volume variation caused by temperature variation. This thermal property provides important information especially for processes that make use of heat transfer pipes and equipment such as heat exchangers. Up to now, there is no data of coefficient of thermal expansion of pulps, and only few literature studying this property in food fluids [36].

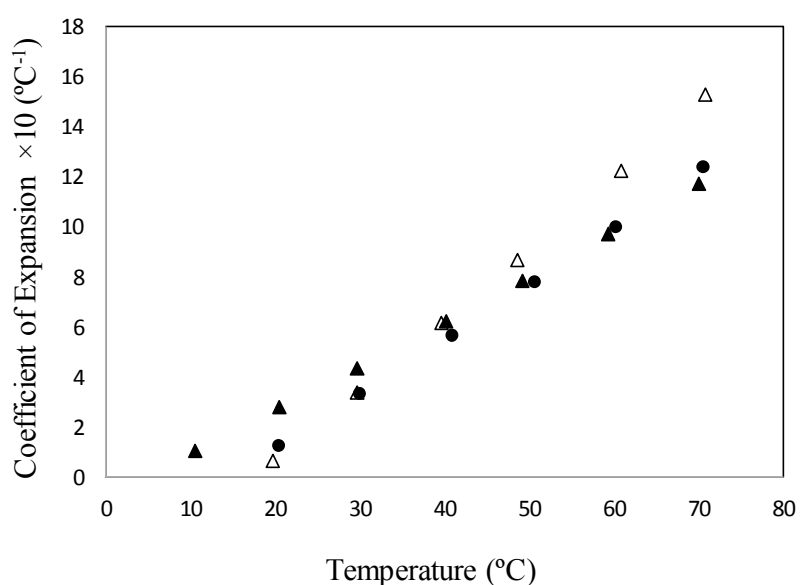

Figure 2. Effect of temperature on coefficient of expansion of mangaba (4),

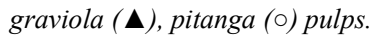

\subsection{Rheological Behavior}

Rheological behavior of the pulps is represented in Figure 3. In all cases, the behavior observed was typically nonNewtonian.

For mangaba and pitanga pulps, increasing the temperature the shear stress decreased, except for mangaba pulp from 10 to $20^{\circ} \mathrm{C}$. Comparing these two pulps, it is verified that the effect of temperature was more expressive for pitanga pulp. On the other hand, the graviola pulp presented a different behavior, there is an inversion on the profile with the temperature, i.e., from $10-30^{\circ} \mathrm{C}$ and $40-50^{\circ} \mathrm{C}$, increasing temperature the shear stress increased. This can be explained by it composition. Graviola is fruit rich in polysaccharides [37] and studies revealed the inversion of viscosity with shear rate when the temperature is increased in fluids containing polysaccharides [38]. This is easily observed in Figure 4.

Observe that for mangaba and pitanga pulps (Figure $4 \mathrm{a}$ and $4 \mathrm{c}$ ) the apparent viscosity decreased with increasing shear rate and temperature. However, there is an inversion for graviola pulp. The behavior presented in Figure $4 \mathrm{~b}$ has been 
attributed to the conformational changes of the molecules (polysaccharides) when present in a shear field [38]. Therefore, the results are coherent since, graviola pulp is characterized by containing high amount of fibers $(22.0 \%$, according to the manufacturer), different from other pulps with low amount of these constituents (4.0 and $4.9 \%$ for mangaba and pitanga pulps, respectively, according to the manufacturer). Evaluating Figures $3 \mathrm{a}$ and $4 \mathrm{a}$, it is believed that the behavior observed for mangaba pulps from 10 to $20^{\circ} \mathrm{C}$ was due to the reorganization of the molecules.

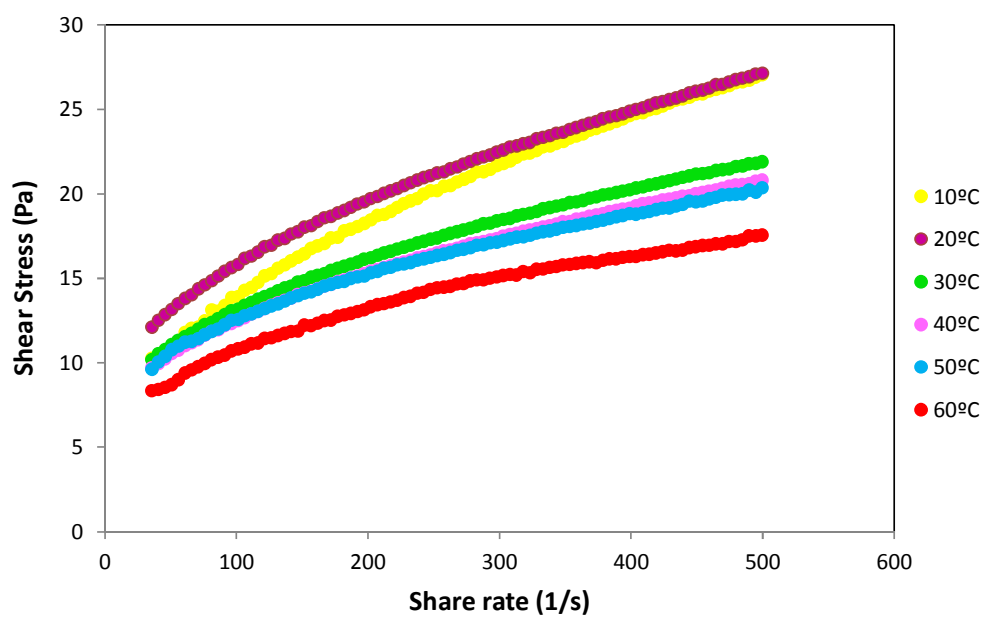

(a)

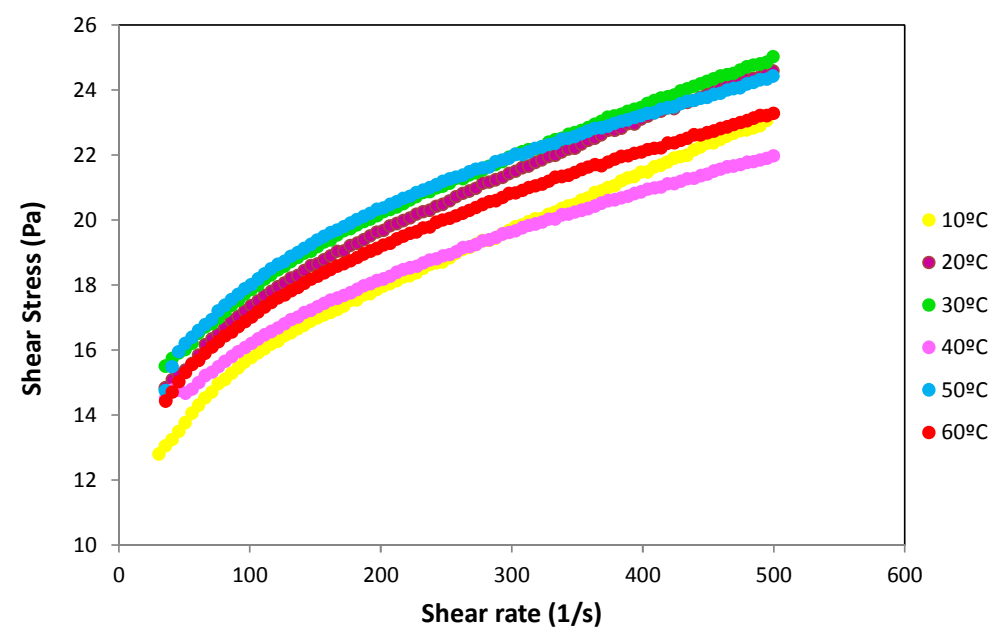

(b)

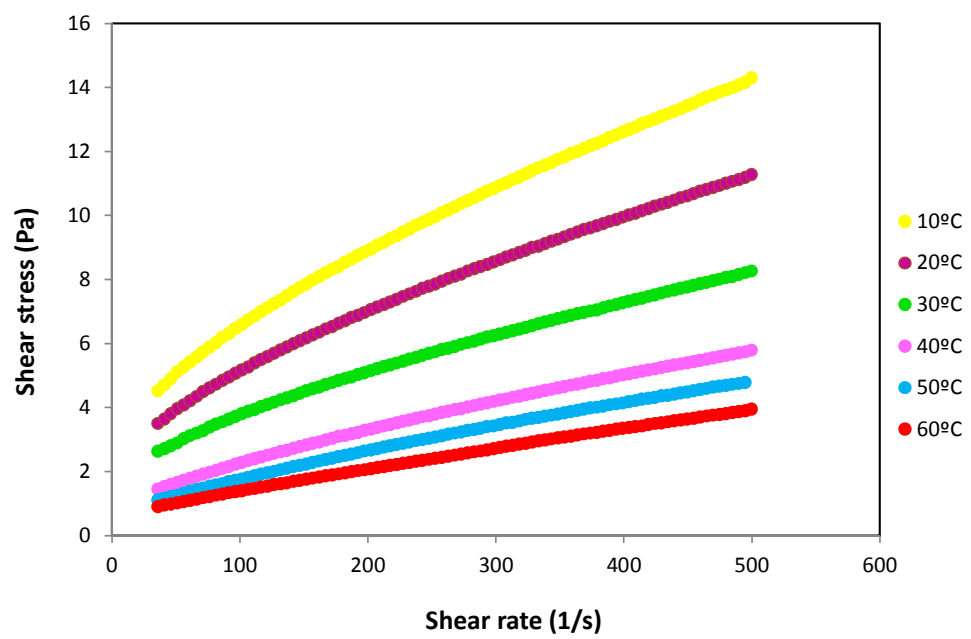

(c)

Figure 2. Rheograms of shear stress versus shear rates plots of pulps at different temperatures: (a) mangaba; (b) graviola, (c) pitanga. 


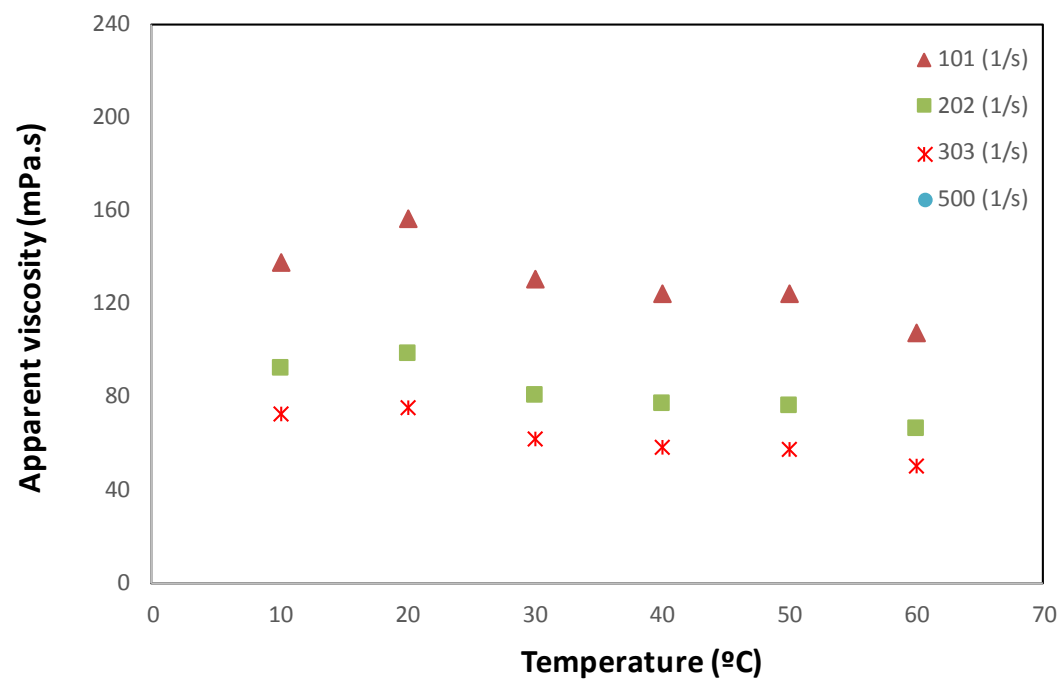

(a)

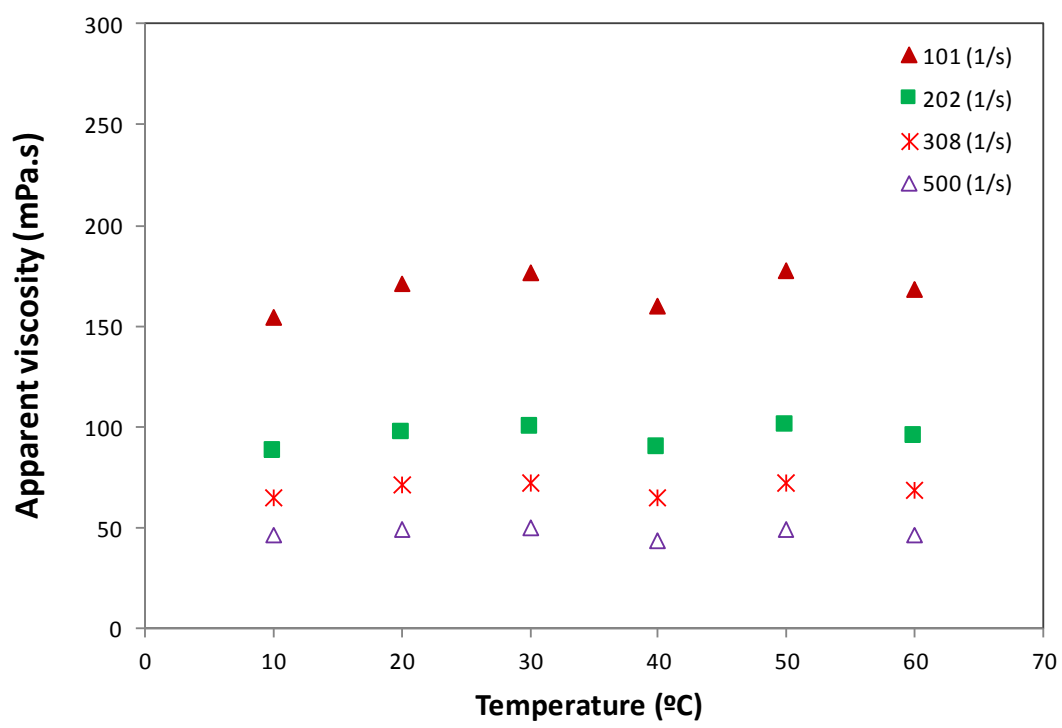

(b)

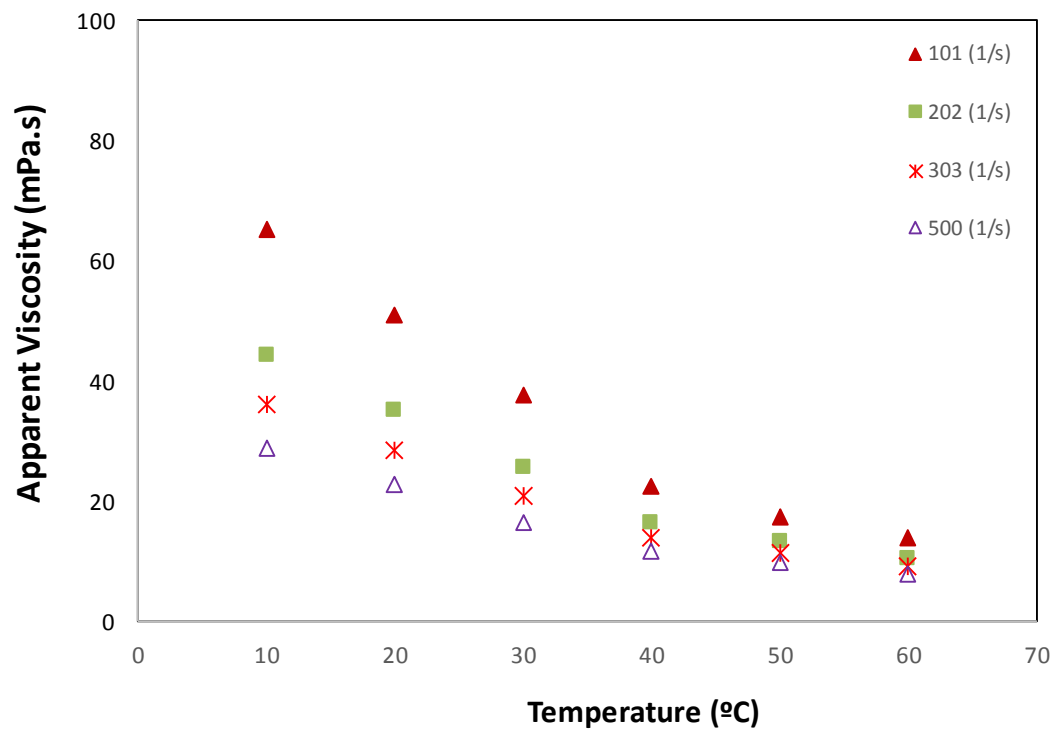

(c)

Figure 4. Effect of temperature on apparent viscosity of pulps at different share rates: (a) mangaba; (b) graviola, (c) pitanga. 
From Figures 3 and 4 it is possible to confirm that all pulps present a clear non-Newtonian profile, specifically classified as being pseudoplastic fluid, due to the apparent viscosity decreasing with increasing shear rate. Using the experimental data, flow curves from each pulp at different temperatures were adjusted to the rheological models (Equations 5-6) and Tables 4-6 present the values for the parameters obtained in the model adjusted for each pulp.

Table 4. Adjustment parameters of different models for the rheological behavior of mangaba pulp at different temperatures.

\begin{tabular}{|c|c|c|c|c|c|c|c|}
\hline \multirow[t]{2}{*}{ Model } & & \multicolumn{6}{|c|}{ Temperature $\left({ }^{\circ} \mathrm{C}\right)$} \\
\hline & & 10 & 20 & 30 & 40 & 50 & 60 \\
\hline \multirow[t]{2}{*}{ Power Law } & $\boldsymbol{K}\left(\mathrm{Pa} \cdot \mathrm{s}^{\mathrm{n}}\right)$ & 2.1634 & 3.5132 & 3.1784 & 3.0319 & 3.3138 & 2.7252 \\
\hline & $n$ & 0.4054 & 0.3268 & 0.3090 & 0.3078 & 0.2896 & 0.2991 \\
\hline \multirow[t]{3}{*}{ Herschel-Bulkley } & $\tau_{0}(\mathrm{~Pa})$ & 3.6701 & 6.4888 & 5.1279 & 5.1015 & 4.6752 & 0.5443 \\
\hline & $\kappa\left(\mathrm{Pa} . \mathrm{s}^{\mathrm{n}}\right)$ & 0.9967 & 0.9681 & 0.9863 & 0.8687 & 1.1339 & 2.4361 \\
\hline & $n$ & 0.5079 & 0.4921 & 0.4561 & 0.4654 & 0.4213 & 0.3122 \\
\hline
\end{tabular}

Table 5. Adjustment parameters of different models for the rheological behavior of graviola pulp at different temperatures.

\begin{tabular}{|c|c|c|c|c|c|c|c|}
\hline \multirow[t]{2}{*}{ Model } & & \multicolumn{6}{|c|}{ Temperature $\left({ }^{\circ} \mathrm{C}\right)$} \\
\hline & & 10 & 20 & 30 & 40 & 50 & 60 \\
\hline \multirow[t]{2}{*}{ Power Law } & $K\left(\mathrm{~Pa} . \mathrm{s}^{\mathrm{n}}\right)$ & 5.6989 & 6.9997 & 7.7607 & 7.5837 & 7.7709 & 7.3822 \\
\hline & $n$ & 0.2193 & 0.1982 & 0.1837 & 0.1678 & 0.1825 & 0.1824 \\
\hline \multirow[t]{3}{*}{ Herschel-Bulkley } & $\tau_{0}(\mathrm{~Pa})$ & 9.6022 & 9.9159 & 11.7670 & 10.5167 & 4.5119 & 7.6585 \\
\hline & $\kappa\left(\mathrm{Pa} . \mathrm{s}^{\mathrm{n}}\right)$ & 0.52965 & 1.0040 & 0.6450 & 0.7624 & 4.4512 & 2.1469 \\
\hline & $n$ & 0.5178 & 0.4298 & 0.4856 & 0.4354 & 0.2398 & 0.3182 \\
\hline
\end{tabular}

Table 6. Adjustment parameters of different models for the rheological behavior of pitanga pulp at different temperatures.

\begin{tabular}{|c|c|c|c|c|c|c|c|}
\hline \multirow[t]{2}{*}{ Model } & & \multicolumn{6}{|c|}{ Temperature $\left({ }^{\circ} \mathrm{C}\right)$} \\
\hline & & 10 & 20 & 30 & 40 & 50 & 60 \\
\hline \multirow[t]{3}{*}{ Power Law } & $\kappa\left(\mathrm{Pa} \cdot \mathrm{s}^{\mathrm{n}}\right)$ & 0.7293 & 0.5568 & 0.4108 & 0.1562 & 0.0994 & 0.0686 \\
\hline & $n$ & 0.4755 & 0.4812 & 0.4796 & 0.5789 & 0.6230 & 0.6485 \\
\hline & $\mathrm{R}^{2}$ & 0.9984 & 0.9986 & 0.9982 & 0.9990 & 0.9990 & 0.9977 \\
\hline \multirow[t]{3}{*}{ Herschel-Bulkley } & $\tau_{0}(\mathrm{~Pa})$ & 2.4510 & 1.1816 & 1.4766 & 0.6762 & 0.5040 & 0.5634 \\
\hline & $\boldsymbol{K}\left(\mathrm{Pa} . \mathrm{s}^{\mathrm{n}}\right)$ & 0.2009 & 0.1676 & 0.1034 & 0.0569 & 0.0378 & 0.0148 \\
\hline & $n$ & 0.6551 & 0.6483 & 0.6725 & 0.7235 & 0.7630 & 0.8740 \\
\hline
\end{tabular}

According to Tables 4-6, models applied in this work presented good adjustment with $\mathrm{R}^{2}>0.99$. However, from Figure 4 it's clear that the Hershel-Bulkley model is more coherent for mangaba and pitanga pulps. For graviola pulp, although both models have presented $\mathrm{R}^{2}>0.99$, due to the inversion, there is no indication for the best model. Actually, both models can promote a good representation of the rheological behavior of tis pulp. From Tables 4-6, it is possible also to confirm that these pulps are pseudoplastic fluids, since $\mathrm{n}<1$ in both models.

The analysis of the effect of temperature by the Arrhenius model corroborates to the facts previously observed. Table 7 presents the parameters of Arrhenius model for the pulps evaluated in this work.

Table 7. Adjustment parameters in the Arrhenius model for mangaba, graviola and pitanga pulps at an apparent viscosity of $303 s^{-1}$.

\begin{tabular}{llll}
\hline \multirow{2}{*}{ Parameters } & \multicolumn{3}{c}{ Pulps } \\
\cline { 2 - 4 } & Mangaba & Graviola & Pitanga \\
\hline $\mathrm{E}_{\mathrm{a}}(\mathrm{J} / \mathrm{mol})$ & 5640.4 & 839.0 & 22467.8 \\
$\mathrm{~B}$ & 1.8790 & 5.7026 & -5.9267 \\
$\mathrm{R}^{2}$ & 0.9972 & 0.3347 & 0.9924 \\
\hline
\end{tabular}

According to Table 7, the pitanga pulp presents the highest activation energy $(22467.8 \mathrm{~J} / \mathrm{mol})$. Higher values of activation energy indicate the rheological behavior of the fluid is more affected by temperature. The values presented in Table 7 confirm the results previously presented Figure 3 and 4 , in which present the effect of temperature on shear stress and apparent viscosity of the pulps.

\section{Conclusion}

In this work the thermophysical and transport propertied of mangaba, graviola and pitanga pulps were determined. The results were coherent with described by literature for this kind of food, and the values of these properties were consistent. Equations were adjusted to experimental data to 
provide the effect of temperature and ${ }^{\circ}$ Brix on density of these pulps, showing good results $\left(\mathrm{R}^{2}>0.99\right)$. All pulps were characterized as a non-Newtonian fluid, specifically as a pseudoplastic fluid, being observed an inversion in the apparent viscosity in the graviola pulp due to the higher amount of fibers. Hershel-Bulkley model presented better results for mangaba and pitanga pulps, being rheological behavior of the last pulp the most sensible to the effect of temperature. The great importance of this work is opened of new possibilities of food industry, given support with real data for the development of industrial products using tropical fruits with new exotic flavors.

\section{References}

[1] Delaplace G, Loubière K, Ducept F, Jeantet R. 4- Dimensional Analysis of Processes Influenced by the Variability of Physical Properties. Dimensional Analysis of Food Process, ISTEPELS, 2015; 356p.

[2] Ahmed J, Al-Attar H. Effect of drying method on rheological, thermal, and structural properties of chestnut flour doughs. Food Hydrocolloid 2015; 51: 76-87.

[3] Steffe JF. Rheological Methods in Food Process Engineering, Freeman Press, 2ndEd., USA, 1996, 428p.

[4] Prado JM, Veggi PC, Pereira CG, Meireles MAA. Cap 19Propriedades térmicas de Alimentos e Propriedades Térmicas da Água. In "Fundamentos de Engenharia de Alimentos", Meireles MAA, Pereira CG (eds), Ed Atheneu, 2013, pp. 832856.

[5] Cindio B, Baldino N, Gabriele D, Lupi FR. Rheological Properties of Food Materials. Refer Mod Food Sci 2016: 610617.

[6] Ahmed J, Shivare U.S., Singh, P. Colour kinetics and rheology of coriander leaf puree and storage characteristics of the paste. Food Chem 2004; 84: 605-611.

[7] Haminiuk CWI, Sierakowski MR, Vidal JRMB, Masson ML. Influence of temperature on the rheological behavior of whole araça pulp (Psidium cattleianum sabine). Food Sci Technol 2006; 39: 426-430.

[8] Silva FC, Guimarães DHP, Gasparetto CA. Rheology of Acerola Juice: Effets of Concentration and temperature. Food Sci Technol 2005; 25: 121-126.

[9] Pereira CG, Resende JV, Giarola TMO. Relationship between the thermal conductivity and rheological behavior of acerola pulp: Effect of concentration and temperature. Food Sci Technol 2014; 58: 446-453.

[10] Rigo M, Bezerra JRMV, Córdova KRV. Study of temperature effect on rheological parameters of the butia pulp (Butia eriospatha). Ambiência 2010; 6: 25-36.

[11] Ferreira GM, Guimarães MJOC, Maia MCA. Effect of temperature and Shear Rate in the Properties of Whole flow Cupuaçu pulp. (Theobroma grandiflorum). Rev Bras Frutic 2008; 30: 385-389.

[12] G. M. Ferreira. A. J. M. Queiroz, R. S. Conceiçao, C. A. Gasparetto. Efeito da temperatura no comportamento reológico das polpas de caju e goiaba. Revista Ciências Exatas e Naturais, 2002, 4:175-184

[13] Sato ACK, Cunha, RL. Influence of temperature on the rheological behavior of jaboticaba pulp. Food Sci Technol 2007; 27: 890-896.

[14] Pelegrine DH, Silva FC, Gasparetto CA. Rheological Behavior of Pineapple and Mango Pulps. Food Sci Technol 2002; 35: 645-648.

[15] Lopes AS, Mattuietto RA, Menezes MC, Silva LHM, Pena ES. Rheological behavior of Brazilian Cherry (Eugenia uniflora L.) pulp at pasteurization temperatures. Food Sci. Technol 2013; 33: 26-31.

[16] Gratão ACA, Silveira Jr. V, Telis-Romero J. Laminar flow of soursop juice through concentric annuli: Friction factors and rheology. J Food Eng 2007; 78: 1343-1354.

[17] Quek MC, Chin NL, Yusof YA. Modelling of rheological behaviour of soursop juice concentrates using shear ratetemperature-concentration superposition. J Food Eng 2013; 118: 380-386.

[18] Bezerra CV, Silva LHM, Costa RDS, Mattieto MA, Rodrigues AMC. Rheological properties of tropical juices. Braz J Food Technol 2013; 16: 155-162.

[19] Epstein L. Mangaba: "coisa boa de comer". Bahia Agric 2004; 6: 19-22.

[20] Ferreira EG, Marinho SJO. Produção de frutos de mangabeira para consumo in natura e industrialização. Technol Ciênc Agrop 2007; 1:9-14.

[21] Alves RE, Filgueiras HAC, Moura CFH. Caracterização de frutas nativas da América Latina. Jaboticabal: Funep, 2000, $66 \mathrm{p}$.

[22] Gavamukulya Y, Abou-Elella F, Wamunyokoli F, AEl-Shemy $\mathrm{H}$. Phytochemical screening, anti-oxidant activity and in vitro anticancer potential of ethanolic and water leaves extracts of Annona muricata (Graviola). Asian Pac J Trop Med. 2014; 7S1:355-63.

[23] Paul J, Gnman R, Jayadepa R, Arul L. Anti cancer activity on Graviola, an exciting medicinal plant extract vs various cancer cell lines and a detailed computational study on its potent anti-cancerous leads. Curr Trop Med Chem 2013; 13: $1666-1673$.

[24] Sun S, Liu J, Kadouh H, Sun X, Zhou K. Three new antiproliferative Annonaceous acetogenins with monotetrahydrofuran ring from graviola fruit (Annona muricata). Bioorg Med Chem Lett 2014; 24: 2773-2776.

[25] Thang TD, Dai DN, Hoi TM, Oqunwande IA. Study on the volatile oil contents of Annona glabra L., Annona squamosa L., Annona muricata L. and Annona reticulata L., from Vietnam. Nat Prod Res 2013; 27: 1232-1236.

[26] Nawwar M, Ayoub N, Hussein S, Hashim A, El-Sharawy R, Wende K, Harms M, Lindequist. A flavonol triglycoside and investigation of the antioxidant and cell stimulating activities of Annona muricata Linn. Arch Pharm Res 2012; 35: 761767.

[27] Matsushige A, Kotake Y, Matsunami K, Otsuka H, Ohta S, Takeda Y. Annonamine, a new aporphine alkaloid from the leaves of Annona muricata. Chem Pharm Bull 2012; 60: 257259. 
[28] Matsushige A, Matsunami K, Kotake Y, Otsuka H, Ohta S. Three new megastigmanes from the leaves of Annona muricata. J Nat Med 2012; 66: 284-291.

[29] Bagetti M, Facco EMP, Piccolo J, Hirsch GE, RodriguezAmaya D, Kobori CN, Vizzotto M, Emanuelli T. Physicochemical characterization and antioxidant capacity of pitanga fruits (Eugenia uniflora L). Food Sci Technol 2011; 31: 147-154.

[30] Schapoval EES, Silveira SM, Miranda ML, Alice CB, Henriques AT. Evaluation of some pharmacological activities of Eugenia uniflora L. J Ethnopharmacol 1994; 44: 137-142.

[31] Normas Analíticas do Instituto Adolfo Lutz. Métodos químicos e físicos para análise de alimentos. $3^{\mathrm{a} e d . ~ S a ̃ o ~ P a u l o, ~}$ $1985,533 \mathrm{p}$.

[32] Cabral RAF, Orrego-Alzate CE, Gabas AL, Telis-Romero J. Rheological and thermophysical properties of blackberry juice. Food Sci Technol 2007; 27: 589-596.

[33] Azoubel PM, Cipriani DC, El-Aouar AA, Antonio GC, Murr FEX. Effect of concentration on the physical properties of cashew juice. J Food Eng 2005; 66: 413-417.
[34] Souza EP, Queiroz AJM, Figueiredo RMF, Santos JEA, Lemos DM. Thermophysical Properties of the Pequi Pulp in Different Concentrations. Biosci J 2016; 32: 20-28.

[35] Magerramov MA, Abdulagatov AI, Abdulagatov IM, Azizov ND. Thermal Conductivity of Peach, Raspberry, Cherry and Plum Juices as a Function of Temperature and Concentrations. J Food Proc Eng 2006: 304-326.

[36] Canciam CA. Prediction of the thermal expansion coefficient of sesame oil (Sesamum indicum L.) by applying linear regression. Revista Exata 2010; 3: 1-8.

[37] Acquarone VM, Menegalli FC, Rodrigues MI. Rheological behavior of soursop (Annona muricata L.) juice as a function of temperature and concentration. In: ORTEGA, E.; PARADA, E.; FITO, P. Equipos y processos para la indústria de alimentos. Tomo I: Propriedades físicas de alimentos. Valência: 1996.

[38] Toneli JTCL, Murr FEX, Park KJ. Estudo da Reologia de Polissacarídeos Utilizados na Indústria de Alimentos. Rev Bras Prod Agroind 2005; 7: 181-204. 